\title{
Terapi Farmakologis Duktus Arteriosus Paten pada Bayi Prematur: Indometasin atau Ibuprofen?
}

\author{
Henry Gunawan, Risma Kerina Kaban \\ Departemen Ilmu Kesehatan Anak, RS Dr Cipto Mangunkusumo, Fakultas Kedokteran Universitas \\ Indonesia, Jakarta
}

\begin{abstract}
Duktus arteriosus paten (DAP) merupakan kelainan yang sering dijumpai pada bayi prematur. Salah satu upaya tata laksana DAP adalah pemberian terapi farmakologis guna memicu penutupan duktus. Sediaan terapi farmakologis yang umumnya digunakan adalah indometasin, suatu penghambat siklooksigenase (COX). Namun akhir-akhir ini diperkenalkan sediaan ibuprofen sebagai alternatif terapi farmakologis yang memiliki efektifitas setara. Dilaporkan seorang bayi prematur (usia gestasi 30 minggu) dengan duktus arteriosus paten yang berhasil di obati menggunakan ibuprofen. Tinjauan literatur menunjukkan terapi ibuprofen pada bayi prematur dengan duktus arteriosus paten memiliki efektifitas tingkat penutupan duktus yang setara dengan indometasin dengan efek samping serebral, gastrointestinal dan renal yang lebih rendah. Keamanan penggunaan ibuprofen pada bayi prematur dengan hiperbilirubinemia masih belum jelas karena efek peningkatan bilirubin yang ditimbulkannya mungkin meningkatkan risiko ensefalopati bilirubin. Di pihak lain, sediaan ibuprofen peroral tampak memiliki efektifitas yang setara dengan sediaan intravena dan efek samping yang terkesan lebih rendah. (Sari Pediatri 2010;11(6):401-8).
\end{abstract}

Kata kunci: duktus arteriosus paten, prematur, terapi farmakologis

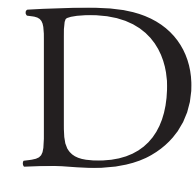
uktus arteriosus paten (DAP) adalah kelainan kongenital yang ditandai oleh adanya kegagalan penutupan duktus arteriosus segera setelah bayi lahir. ${ }^{1}$ Pada bayi normal, duktus arteriosus secara fungsional

\footnotetext{
Alamat korespondensi:

Dr. Risma Kerina Kaban, Sp.A. Divisi Perinatologi. Departemen Ilmu Kesehatan Anak FKUI-RSCM. Jl. Salemba no. 6. Jakarta 10430. Telepon: $021-3154020$
}

menutup dalam waktu 12-24 jam setelah lahir dan mengalami penutupan sempurna dalam waktu tiga minggu. ${ }^{2}$ Kelainan ini sering dijumpai pada bayi prematur dengan insidens 8 per 1000 kelahiran sedangkan insidens pada bayi aterm lebih kecil yaitu 1 per 2000 kelahiran. $^{3}$ Deselina B dkk ${ }^{4}$ pada tahun 2004 melaporkan insidens DAP pada bayi prematur di Departemen Ilmu Kesehatan Anak (IKA) Rumah Sakit Cipto Mangunkusumo (RSCM) 14\%.

Manifestasi klinis DAP bervariasi dari asimtomatik 
hingga manifestasi oversirkulasi pulmoner tergantung dari ukuran DAP. 5 Pendekatan diagnosis dilakukan dengan menemukan tanda klinis seperti murmur kontinyu pada sela iga 2-3 sisi kiri sternum, prekordium yang hiperaktif, peningkatan tekanan nadi dengan nadi yang keras (bounding pulses), hipotensi, edema paru (takipnea, suara ronki, apnea), dan gagal jantung. Diagnosis pasti ditegakkan berdasarkan pemeriksaan ekokardiografi yang dapat memberikan informasi ukuran dan bentuk DAP, serta pola/arah pirau dan derajat berat ringan overperfusi pulmonal. ${ }^{6}$

Tata laksana DAP meliputi tata laksana kegawatan pernafasan, pembatasan cairan, pemberian diuretik, dan penutupan DAP melalui pengobatan farmakologis maupun pembedahan. Pada bayi prematur, pengobatan farmakologis guna memicu penutupan DAP masih merupakan pilihan utama karena efektifitasnya cukup tinggi. Terapi yang umum digunakan adalah pemberian indometasin, suatu penghambat siklooksigenase $(C O X)$. Dilaporkan efektifitas pemberian indometasin pada bayi prematur $80 \% .^{7}$ Pada akhir-akhir ini diperkenalkan sediaan lain yaitu ibuprofen, suatu penghambat siklooksigenase nonselektif lain yang digunakan sebagai pengobatan alternatif. Laporan yang ada menyebutkan bahwa ibuprofen memiliki efektifitas setara dengan indometasin, namun pengalaman dan penelitian klinis dalam penggunaannya pada bayi prematur di Indonesia masih sangat terbatas.

\section{Kasus}

Seorang bayi lahir prematur (usia gestasi 30 minggu) dari ibu berusia 26 tahun, G3 P1 A1 melalui bedah cesar atas indikasi infeksi intrauterin. Ibu datang ke RSCM atas rujukan dari bidan Puskesmas dengan ketuban pecah sejak dua hari sebelum masuk rumah sakit. Ibu selanjutnya dirawat dengan diagnosis ketuban pecah dini, infeksi saluran kemih, dan oligohidramnion. Riwayat pemeriksaan antenatal dikatakan teratur dan tidak didapatkan penyakit atau komplikasi lain selama kehamilan. Selama dua hari perawatan sebelum terminasi kehamilan ibu sempat mendapat injeksi deksametason dua dosis. Pasien lahir dengan berat 1510 gram, panjang $43 \mathrm{~cm}$ dengan skor APGAR menit pertama 6 dan menit kelima 8. Saat lahir pasien mendapat pembersihan jalan nafas, diberikan O2 5 liter per menit melalui masker dan stimulasi taktil. Pasien berespon baik kemudian dirawat di ruang transisi, namun tidak lama kemudian pasien terlihat sesak napas dengan nafas cuping hidung, retraksi dada, dan grunting. Pasien selanjutnya mendapat ventilasi tekanan positif dengan neopuff dan dialih rawat ke ruang perawatan intensif neonatal (NICU) dengan diagnosis neonatus kurang bulan sesuai masa kehamilan, distress pernafasan et causal tersangka sepsis awitan dini, diagnosis banding dengan penyakit membran hialin. Pasien dipasang CPAP, dilakukan septic work-up, foto toraks, dan diberi antibiotik. Pada hari perawatan kedua, pasien mengalami peningkatan usaha nafas dan perburukan profil gas darah sehingga dilakukan intubasi dan diberikan bantuan nafas dengan ventilator. Hari perawatan keempat, dari pemeriksaan fisis ditemukan murmur kontinyu derajat 3/6 pada pinggir kiri atas sternum. Pasien kemudian dilakukan ekokardiografi dan didapatkan DAP besar dengan ukuran 2,5 mm dengan pirau kiri ke kanan, dilatasi ringan atrium kiri, defek septum atrium kecil dan patent foramen ovale. Pasien direncanakan untuk diberikan indometasin oral, namun saat itu belum diberikan karena pasien masih harus dipuasakan. Pada hari perawatan ke 11 dilakukan ekokardiografi ulang dengan hasil masih terdapat DAP dengan ukuran 1,4$1,8 \mathrm{~mm}$, dilatasi ringan atrium dan ventrikel kiri, dan dilatasi arteri pulmoner utama. Pasien selanjutnya diberi indometasin atau ibuprofen. Pada hari perawatan ke 16, ibuprofen mulai diberikan dengan dosis 10 $\mathrm{mg} / \mathrm{kgBB}$ hari pertama, diikuti dengan dosis $5 \mathrm{mg} /$ $\mathrm{kgB}$ hari kedua dan hari ketiga. Pada hari perawatan ke duapuluh, pasien dilakukan ekokardiografi ulang dengan hasil DAP sudah menutup.

\section{Masalah klinis}

Pemilihan ibuprofen oral sebagai terapi farmakologis untuk memicu penutupan DAP pada kasus ini berdasar pada ketersediaan obat, karena di Indonesia pada saat ini indometasin oral sulit untuk diperoleh. Meskipun demikian pengalaman klinis terhadap penggunaan ibuprofen baik dari segi efektifitas maupun keamanannya dibandingkan dengan indometasin di bagian Perinatologi FKUI-RSCM sangat terbatas. Untuk itu diformulasikan pertanyaan klinis sebagai berikut: "Pada bayi prematur dengan DAP, apakah ibuprofen memberikan hasil yang sama atau lebih baik dibandingkan dengan indometasin dan bagaimanakah tingkat keamanannya?" 


\section{Metode/strategi penelusuran bukti}

Prosedur pencarian literatur untuk menjawab masalah klinis di atas adalah dengan menelusuri kepustakaan secara online dengan mempergunakan instrumen pencari Pubmed, Highwire, Cochrane Library, Google, dan Yahoo. Kata kunci yang dipergunakan adalah "patent ductus arteriosus", "prematurity", "ibuprofen", dan "indomethacin" dengan menggunakan batasan (limit): publikasi bahasa Inggris dan penelitian pada manusia.

Dengan metode tersebut, pada awalnya didapatkan 119 artikel yang memenuhi kriteria pemilihan. Setelah penelusuran abstrak artikel-artikel tersebut, didapatkan 21 artikel yang relevan dengan masalah, yaitu satu studi kohort retrospektif, tiga artikel uji klinis, 15 artikel uji klinis acak, satu artikel review, dan satu artikel meta-analisis. Levels of evidence ditentukan berdasarkan klasifikasi yang dikeluarkan oleh Oxford Centre for Evidence-based Medicine Levels of Evidence. ${ }^{8}$

\section{Hasil penelusuran}

Sebuah meta-analisis oleh Thomas RL $\mathrm{dkk}^{9}$ tahun 2004 menelaah 9 uji klinis acak $(n=566)$ yang membandingkan efikasi dan keamanan ibuprofen dan indometasin intravena (IV) sebagai terapi DAP (Tabel 1). Telaah ini menunjukkan dari seluruh uji klinis acak tidak terdapat perbedaan yang bermakna dalam efikasi antara ibuprofen dan indometasin dalam menginduksi penutupan DAP $(p=0,70)$. Lima dari sembilan uji klinis acak tersebut $(\mathrm{n}=443)$ menunjukkan peningkatan kadar kreatinin serum dan penurun- an urine output yang secara bermakna tampak lebih rendah pada ibuprofen dibandingkan indometasin $(p<0,001)$. Penelitian tersebut mendapatkan perbedaan yang tidak bermakna dalam hal mortalitas, perdarahan intraventrikular, enterokolitis nekrotikans (NEC), ligasi bedah, sepsis, retinopati prematuritas, leukomalasia periventrikular, lama perawatan di rumah sakit, perdarahan gastrointestinal, terbukanya kembali DAP, tata laksana tambahan, terapi surfaktan, dan lama pemakaian alat bantu nafas. (Level of evidence: 1a)

Penelitian Mosca F dkk ${ }^{10}$ dalam meta-analisis yang membandingkan efek ibuprofen dan indometasin IV terhadap perfusi serebral dan oksigenasi, mendapatkan bahwa indometasin secara bermakna menurunkan volume darah serebral (maksimal: $320 \pm 171 \mu \mathrm{L} / 100 \mathrm{~g}$ ). Empat dari delapan pasien yang mendapat indometasin mengalami penurunan kadar sitokrom oksidase teroksidasi suatu petanda tingkat oksigenasi $(0,68 \pm$ $0.98 \mu \mathrm{mol} / \mathrm{L}$, non-signifikan). Kecepatan aliran darah serebral juga mengalami penurunan bermakna pada kelompok indometasin berdasarkan pemeriksaan USG Doppler. Hal serupa tidak dijumpai pada kelompok ibuprofen. ${ }^{10}$ (Level of evidence: $2 b$ )

Penelitian Patel J dkk ${ }^{11}$ tahun 2000 membandingkan efek ibuprofen dan indometasin IV terhadap hemodinamik serebral juga mendapatkan hasil yang sesuai dengan Mosca. Pada kelompok indometasin terjadi penurunan aliran darah serebral yang bermakna (sebelum dosis pertama $13,6 \pm 4,1 \mathrm{ml} / 100 \mathrm{~g} / \mathrm{min}$, sesudah dosis pertama $8,3 \pm 3,1 \mathrm{ml} / 100 \mathrm{~g} / \mathrm{min}, \mathrm{p}<0,001$ ), sedangkan pada kelompok ibuprofen hal ini tidak ditemukan (sebelum dosis pertama 13,3 $\pm 3,2 \mathrm{ml} / 100 \mathrm{~g} /$ min, sesudah dosis pertama $14,9 \pm 4,7 \mathrm{ml} / 100 \mathrm{~g} / \mathrm{min}$ ).

Tabel 1. Daftar uji klinis acak dengan dosis dan jadwal terapi ibuprofen dibandingkan indometasin

\begin{tabular}{|c|c|c|c|}
\hline \multirow{2}{*}{ Uji Klinis Acak } & \multirow{2}{*}{$\mathrm{n}$} & \multicolumn{2}{|c|}{ Dosis (mg/kg) } \\
\hline & & Ibuprofen & Indometasin \\
\hline Patel dkk 1995 & 33 & Dua kelompok: 5 atau 10 & 0,1 \\
\hline Mosca dkk 1997 & 16 & $10 \times 5 \times 5$ interval 24 jam & $0,2 \times 0,1 \times 0,1$ interval 24 jam \\
\hline Van Overmiere dkk 1997 & 40 & $10 \times 5 \times 5$ interval 24 jam & $0,2 \times 0,2 \times 0,2$ interval 12 jam \\
\hline Pezzati dkk 1999 & 17 & $10 \times 5 \times 5$ interval 24 jam & $0,2 \times 0,1 \times 0,1$ interval 12 jam \\
\hline Patel dkk 2000 & 33 & $10 \times 5 \times 5$ interval 24 jam & $0,2-0,25$ interval $12 \mathrm{jam}$ \\
\hline Van Overmiere dkk 2000 & 148 & $10 \times 5 \times 5$ interval 24 jam & $0,2 \times 0,2 \times 0,2$ interval 12 jam \\
\hline Lago dkk 2002 & 175 & $10 \times 5 \times 5$ interval 24 jam & $0,2 \times 0,2 \times 0,2$ interval 12 jam \\
\hline Plavka dkk 2001 & 41 & $8 \times 8 \times 8$ interval 24 jam & $0,2 \times 0,2 \times 0,2$ interval 24 jam \\
\hline Su dkk 2003 & 63 & $10 \times 5 \times 5$ interval 24 jam & $0,2 \times 0,2 \times 0,2$ interval 12 jam \\
\hline
\end{tabular}

Sari Pediatri, Vol. 11, No. 6, April 2010 
Henry Gunawan dkk: Terapi farmakologis duktus arteriosus paten pada bayi prematur: indometasin atau ibuprofen?

Tabel 2. Tingkat penutupan DAP

\begin{tabular}{lcccc}
\hline \multirow{2}{*}{ Uji Klinis Acak } & $\mathrm{n}$ & \multicolumn{2}{c}{ Penutupan DAP } & Nilai p \\
\cline { 3 - 4 } & & Ibuprofen & Indometasin & \\
\hline Patel dkk 1995 & 33 & $10 / 18$ & $8 / 15$ & 0,898 \\
Mosca dkk 1997 & 16 & $8 / 8$ & $8 / 8$ & 1,000 \\
Van Overmiere dkk 1997 & 40 & $16 / 20$ & $15 / 20$ & 0,705 \\
Pezzati dkk 1999 & 17 & $9 / 9$ & $8 / 8$ & 0,957 \\
Patel dkk 2000 & 33 & $14 / 18$ & $14 / 15$ & 0,215 \\
Van Overmiere dkk 2000 & 148 & $52 / 74$ & $49 / 74$ & 0,596 \\
Lago dkk 2002 & 175 & $69 / 94$ & $56 / 81$ & 0,533 \\
Plavka dkk 2001 & 41 & $18 / 21$ & $17 / 20$ & 0,948 \\
Su dkk 2003 & 63 & $27 / 32$ & $25 / 31$ & 0,697 \\
Total & 566 & $223 / 294$ & $200 / 272$ & 0,700 \\
\hline
\end{tabular}

Rerata perubahan volume darah serebral (ml/100g) setelah dosis pertama pada kelompok indometasin $-0,4$ $(-0,3 \mathrm{~s} / \mathrm{d}-0,6)$ sedangkan pada kelompok ibuprofen 0.0 $(0,1 \mathrm{~s} / \mathrm{d}-0,1)$, berbeda bermakna $(\mathrm{p}<0,001)$. Hantaran oksigen serebral menurun secara bermakna pada kelompok indometasin namun tidak pada kelompok ibuprofen. ${ }^{11}$ (Level of evidence: $1 b$ )

Penelitian Pezzati M dkk ${ }^{12}$ dalam meta-analisis juga membandingkan efek indometasin dan ibuprofen i.v terhadap aliran darah renal dan mesenterium. Didapatkan bahwa indometasin secara bermakna menyebabkan penurunan aliran darah renal dan mesenterium 30 menit setelah pemberian dan tidak kembali naik ke nilai sebelum terapi setelah 120 menit sedangkan hal tersebut tidak dijumpai pada pasien yang mendapat ibuprofen. (Level of evidence: 2b)

Chotigeat U dkk ${ }^{13}$ tahun 2003 di Thailand melakukan uji klinis acak yang membandingkan ibuprofen oral dengan indometasin i.v pada 30 bayi prematur usia gestasi $\leq 35$ minggu dengan DAP simptomatik. Tingkat penutupan duktus dilaporkan 46,7\% (7/15) pada kelompok ibuprofen oral dan 66,7\% (10/15) pada kelompok indometasin i.v. Enam kasus pada kelompok ibuprofen oral dan 5 kasus pada kelompok indometasin i.v memerlukan terapi farmakologis ulang. Penelitian Chotigeat juga mendapatkan perbedaan bermakna dalam penggunaan diuretik yaitu 11 kasus kelompok indometasin dan 3 kasus kelompok ibuprofen $(\mathrm{p}=0,009)$ sedangkan kejadian NEC dijumpai pada $66,7 \%$ kelompok indometasin dan 40\% kelompok ibuprofen namun secara statistik berbeda tidak bermakna. (Level of evidence: $2 b$ )

Supapannachart $S \mathrm{dkk}^{14}$ tahun 2002 dari Thailand melakukan uji klinis acak membandingkan ibuprofen oral dengan indometasin oral atau i.v pada 18 bayi prematur dengan usia gestasi $<34$ minggu dan DAP simtomatik. Penelitiannya mendapatkan tingkat penutupan DAP 7/9 (78\%) pada kelompok ibuprofen oral dan 8/9 (89\%) pada kelompok indometasin ( $\mathrm{p}$ $>0.05$ ). (Level of evidence: $2 b$ )

Studi retrospektif oleh Fanos V dkk ${ }^{15}$ tahun 2004 yang meneliti efikasi antara ibuprofen i.v versus indometasin i.v pada 40 bayi prematur dengan DAP mendapatkan tingkat penutupan duktus $80 \%$ untuk ibuprofen dan $75 \%$ untuk indometasin. Penelitian tersebut mendapatkan kesan bahwa indometasin lebih nefrotoksik dibanding ibuprofen berdasar pada penurunan kadar kreatinin serum ke normal yang lebih lambat pada kelompok tersebut, namun perbedaannya secara statistik tidak bermakna. (Level of evidence: $3 b$ )

Pada tahun 2003, Heyman E dkk ${ }^{16}$ di Israel melakukan studi prospektif pendahuluan yang meneliti efektifitas dan keamanan suspensi ibuprofen oral pada 22 bayi prematur yang menderita DAP dan sindrom distress pernafasan dengan dosis pemberian yang sama dengan dosis i.v yaitu $10 \mathrm{mg} / \mathrm{kg}$ pertama diikuti dua dosis $5 \mathrm{mg} / \mathrm{kg}$ berikutnya dengan interval 24 jam. Tingkat penutupan DAP 95,5\%, tidak didapatkan kejadian ductus reopening, dan ditemukan perbedaan bermakna pada kadar kreatinin serum sebelum dan sesudah terapi. (Level of evidence: $2 b$ )

Tahun 2005, Pourarian S dkk ${ }^{17}$ di Iran melakukan uji klinis acak yang membandingkan pemberian ibuprofen oral dengan indometasin oral pada 20 bayi prematur dengan DAP, mendapatkan penutupan duktus sempurna pada 8/10 bayi pada kelompok ibuprofen dan 7/10 bayi pada kelompok indometasin, 
Henry Gunawan dkk: Terapi farmakologis duktus arteriosus paten pada bayi prematur: indometasin atau ibuprofen?

tidak dijumpai dengan perbedaan yang secara statistik. Penelitian ini tidak mendapatkan kejadian ductus reopening, maupun peningkatan BUN dan kreatinin serum yang berlebihan pada kedua kelompok. (Level of evidence: $2 b$ )

Berikutnya Fakhraee SH $\mathrm{dkk}^{18}$ dari Iran tahun 2007 melakukan uji klinis serupa pada 36 bayi prematur usia gestasi $\leq 34$ minggu dengan DAP mendapatkan tingkat tingkat penutupan duktus $100 \%(18 / 18)$ pada kelompok ibuprofen dan 83,3\% (15/18) pada kelompok indometasin $(p>0,05)$. Peneliti mendapatkan perbedaan tidak bermakna pada kadar BUN dan kreatinin serum kedua kelompok sebelum dan sesudah terapi, namun tiga pasien pada kelompok indometasin mengalami enterokolitis nekrotikans (NEC) dengan satu pasien diantaranya meninggal. (Level of evidence: 2b)

Di tahun yang sama Hammerman $\mathrm{C} \mathrm{dkk}^{19}$ melakukan uji klinis acak dengan membandingkan pemberian ibuprofen i.v dengan indometasin infus kontinyu pada 64 bayi prematur (usia gestasi $\leq 33$ minggu, berat lahir $\leq 1750 \mathrm{~g}$ ) dengan DAP. Dilaporkan tingkat penutupan duktus yang sebanding ( $74 \%$ vs $59 \%$, $\mathrm{p}=0,123$ ). Demikian pula dengan tingkat ulangan terapi dan ligasi bedah pada kedua kelompok. Tampak bahwa pemberian indometasin secara infus kontinyu meniadakan efek vasokonstriksi perifer yang biasa dijumpai pada pemberian indometasin bolus i.v. Pemeriksaan kadar kreatinin serum, oliguria, perkiraan laju filtrasi glomerulus, fraksi ekskresi natrium maupun parameter kecepatan aliran darah renal, mesenterium superior dan arteri serebral anterior tampak serupa pada kedua kelompok. (Level of evidence: $1 b$ )

Pada tahun 2008 Cherif A dkk ${ }^{20}$ melakukan uji klinis acak pendahuluan yang membandingkan efektivitas dan toleransi ibuprofen oral dan ibuprofen i.v pada 64 bayi berat lahir sangat rendah dengan DAP dan distress nafas mendapatkan tingkat penutupan duktus cenderung lebih tinggi pada kelompok oral (84,3\% versus $62,5 \%)$. Penutupan duktus setelah satu atau dua dosis terapi terlihat pada 19/27 (70,3\%) kelompok ibuprofen oral dan 14/20 (70\%) kelompok ibuprofen i.v. Efek samping seperti oliguria dan peningkatan kadar kreatinin serum meningkat pada kelompok ibuprofen i.v (31.2\% versus 9.3\%), namun perbedaannya tidak bermakna. Efek samping secara bermakna lebih rendah bila penutupan duktus tercapai sebelum dosis penuh diberikan (23,1\% versus $76,9 \%)$. (Level of evidence: 1b)

\section{Pembahasan}

Terapi ligasi bedah merupakan terapi utama untuk menutup DAP, namun karena tindakan ligasi bedah disertai banyak risiko seperti perburukan fungsi pernafasan, fluktuasi tekanan darah, perdarahan intrakranial, infeksi, kilotoraks, paralisis saraf laring, dan kematian, maka terapi farmakologis menjadi terapi alternatif pilihan pertama dalam menginduksi penutupan DAP. Telah diketahui bahwa patensi duktus arteriosus selama masa fetus dipertahankan oleh beberapa faktor antara lain prostaglandin dan tekanan oksigen (pO2) yang rendah sehingga penggunaan penghambat prostaglandin memiliki tempat pada tata laksana kelainan ini. Senyawa penghambat siklooksigenase (cox inhibitor) merupakan sediaan yang dipakai untuk tujuan ini melalui efeknya dalam menghambat konversi asam arakidonat menjadi bermacam prostaglandin. Di dalam tubuh terdapat 3 macam isoenzim yaitu cox 1 , cox 2 dan $\operatorname{cox} 3$. Indometasin merupakan salah satu penghambat cox yang telah dipakai sebagai terapi standar yang efektif untuk memicu penutupan duktus pada bayi prematur dengan DAP. Namun pemakaiannya diketahui banyak disertai dengan timbulnya berbagai efek samping pada gastrointestinal, serebral dan renal yang tidak diinginkan karena efek penghambatan yang lebih kuat pada cox 1. Akhir-akhir ini ibuprofen mulai diperkenalkan sebagai terapi alternatif yang dikatakan memiliki efektifitas yang baik. Hasil penelusuran artikel yang telah dilakukan ini memang mengesankan bahwa tingkat efektifitas ibuprofen dalam menginduksi penutupan DAP tampak setara dengan indometasin. Baik dalam sediaan yang diberikan secara intravena maupun per oral tidak terdapat perbedaan yang bermakna di antara keduanya.

Pada studi-studi yang dilakukan dengan menggunakan sediaan intravena ternyata bahwa ibuprofen terkesan memiliki lebih sedikit efek negatif pada gastrointestinal, serebral, dan terutama pada fungsi ginjal dibandingkan dengan indometasin. Ibuprofen memiliki efek penghambatan cox 1 yang lebih ringan dibandingkan indometasin sehingga kurang menimbulkan efek vasokonstriksi. ${ }^{21}$

Penelitian oleh Hammerman $\mathrm{C} \mathrm{dkk}^{19}$ yang mencoba menggunakan indometasin infus kontinyu sebagai pembanding dengan ibuprofen i.v ternyata mendapatkan bahwa pemberian indometasin secara infus kontinyu terkesan mampu meniadakan dampak 
negatif dari pemberian indometasin secara bolus. Hal ini mengesankan bahwa dengan memperlambat laju obat yang masuk dalam sirkulasi dapat menghilangkan efek vasokonstriksi yang ditimbulkannya. Namun walaupun pada penelitian ini indometasin infus kontinyu tampak memiliki efikasi yang sama dalam penutupan duktus, studi ini tidak cukup kuat untuk membuktikan secara definitif bahwa indometasin infus kontinyu ini memiliki efikasi terapeutik yang sebanding.

Beberapa penelitian lain yang mencoba membandingkan sediaan ibuprofen maupun indometasin peroral di negara-negara yang tidak tersedia sediaan intravena ternyata mendapatkan hasil yang cukup memuaskan yaitu tingkat penutupan duktus yang sebanding. Hal serupa terlihat bahwa efek negatif dari pemberian indometasin bolus intravena tidak dijumpai pada pemberian per oral, terbukti tidak terdapat perbedaan pada parameter fungsi ginjal di kedua kelompok. Disebabkan oleh absorbsi obat per oral relatif lebih lambat masuk ke dalam sirkulasi, sehingga mengurangi atau meniadakan efek vasokonstriksi dari indometasin.

Selanjutnya mengenai perbandingan antara pemberian ibuprofen peroral dengan intravena, penelitian Cheriff $\mathrm{A} \mathrm{dkk^{20 }}$ mendapatkan efektifitas sediaan peroral setara dengan sediaan intravena, sedangkan efek samping lebih rendah. Penelitian mengenai farmakokinetik ibuprofen oral pada bayi prematur masih sangat sedikit. Studi pendahuluan yang dilakukan oleh Raju NV dkk ${ }^{22}$ pada sejumlah kecil bayi prematur melaporkan bahwa ibuprofen diabsorsi dengan cepat setelah pemberian peroral dan kadar puncak dalam plasma tercapai setelah satu sampai dua jam, sedangkan Sharma PK dkk ${ }^{23}$ melaporkan adanya variasi antar individu dalam konsentrasi plasma dan waktu paruh. Absorbsi ibuprofen oral yang relatif lebih lambat dibandingkan dengan jalur intravena dan waktu paruh yang lebih lama dalam hal ini mungkin memperpanjang waktu kontak dengan duktus sehingga meningkatkan respon terapi.

Di Indonesia indometasin oral untuk saat ini sulit diperoleh, sedangkan indometasin maupun ibuprofen intravena dari semula memang tidak tersedia, sehingga pilihan terapi satu-satunya adalah ibuprofen oral. Penelitian yang telah ditelaah secara kasar memberikan kesan bahwa ibuprofen oral tampak lebih baik dibandingkan sediaan lain dalam hal efektifitas ibuprofen oral ini setara dengan ibuprofen intravena sedangkan efek sampingnya tampak lebih rendah. Namun demikian masih diperlukan penelitianpenelitian yang lebih baik untuk membuktikan kemaknaannya secara klinis.

Mengenai efek lain dari ibuprofen, penelitian terpisah oleh Cooper-Peel C dkk ${ }^{24}$ dan Ahlfors CE ${ }^{25}$ yang menguji efek ibuprofen intravena terhadap ikatan bilirubin-albumin mendapatkan bahwa ibuprofen meningkatkan konsentrasi bilirubin indirek bebas. Sedangkan Zecca E dkk ${ }^{26}$ mendapatkan bahwa pemberian ibuprofen intravena pada bayi prematur berhubungan dengan peningkatan kadar puncak bilirubin serum total, sehingga penggunaan ibuprofen intravena pada bayi prematur yang sakit mungkin akan meningkatkan risiko terjadinya ensefalopati bilirubin. Hal ini juga menimbulkan pertanyaan mengenai bagaimana dampak jangka panjang pemberian ibuprofen intravena pada aspek neurodevelopmental anak di kemudian hari. Terlepas dari kenyataan tersebut belum terdapat suatu uji klinis yang melaporkan apakah pemberian ibuprofen secara per oral akan memiliki efek yang sama dengan ibuprofen intravena terhadap kadar bilirubin serum.

Indikasi terapi farmakologis pada kasus kami adalah DAP ukuran $>1,5 \mathrm{~mm}(2,5 \mathrm{~mm})$, disertai pirau dari kiri ke kanan dan ditemukan dilatasi atrium kiri. ${ }^{21}$ Pemberian ibuprofen oral mulai diberikan pada hari perawatan ke-16 setelah terdapat toleransi asupan oral, uji fungsi ginjal normal, dan tidak terjadi penutupan DAP spontan berdasarkan pemeriksaan ekokardiografi yang kedua. Setelah satu seri terapi, DAP menutup. Pada perjalanan klinis selama terapi hingga pasien dipulangkan tidak dijumpai komplikasi. Hasil pemeriksaan ultrasonografi kepala normal. Namun pada pasien tidak dilakukan pemeriksaan parameter fungsi ginjal selama pemberian ibuprofen dan juga tidak dilakukan ekokardiografi ulang untuk melihat apakah terjadi ductus reopening atau tidak.

\section{Kesimpulan}

Terapi farmakologis ibuprofen pada bayi prematur yang menderita DAP memiliki efektifitas tingkat penutupan duktus yang setara dengan indometasin. Efek samping berupa vasokonstriksi pada aliran darah serebral, gastrointestinal dan renal, tampak lebih rendah dibandingkan dengan indometasin. Namun keamanan ibuprofen pada bayi prematur sakit dengan hiperbilirubinemia baik jangka pendek 
maupun jangka panjang masih belum jelas karena efek peningkatan bilirubin indirek bebas maupun bilirubin total yang ditimbulkannya mungkin meningkatkan risiko terjadinya ensefalopati bilirubin. Sediaan peroral tampak memiliki efektifitas yang setara dengan dengan sediaan intravena dengan efek samping yang terkesan lebih rendah, walaupun masih diperlukan uji klinis lebih lanjut (multicenter randomised controlled trial) untuk secara definitif membuktikan hal ini.

\section{Daftar Pustaka}

1. Milliken JC. Patent ductus arteriosus. Emedicine. Diunduh dari www.emedicine.com. Diakses tanggal 18 Juli 2009.

2. Moore P, Brooke MM, Heymann MA. Patent ductus arteriosus and aortopulmonary window. Dalam: Allen HD, Driscoll DJ, Shaddy RE, Feltes TF, penyunting. Moss and Adams' heart disease in infants, children, and adolescents: including the fetus and young adults, Edisi ke-7. Lippincott :Williams \& Wilkins; 2008.h.683701

3. Sethuraman G. Patent ductus arteriosus. Emedicine. Diunduh dari www.emedicine.com. Diakses tanggal 18 Juli 2009.

4. Deselina B, Putra ST, Suradi R. Prevalence of patent ductus arteriosus in premature infants at the neonatal ward, Cipto Mangunkusumo hospital, Jakarta. Paediatr Indones 2004;44:223-27.

5. Neish SR. Patent ductus arteriosus. Emedicine. Diunduh dari www.emedicine.com Diakses tanggal 18 Juli 2009.

6. Gomella TL. Cardiac abnormalities. Dalam: Cunningham MD, Eyal FG, Zenk KE, penyunting. Neonatology: management, procedures, on-call problems, diseases, and drugs. Edisi ke-5. McGraw-Hill;2004.h.354-63.

7. Wechsler SB, Wernovsky G. Cardiac disorders. Dalam: Cloherty JP, Eichenwald EC, Stark AR, penyunting. Manual of neonatal care. Edisi ke-5. Lippincott: Williams \& Wilkins; 2004.h.407-60.

8. Oxford Centre of Evidence-based Medicine. Oxford centre for evidence-based medicine levels of evidence (March 2009). Diunduh dari: http://www.cebm.net/index. asox?o=1025. Diakses tanggal 18 Juli 2009.

9. Thomas RL, Parker GC, Van Overmeire B, Aranda JV. A meta-analysis of ibuprofen versus indomethacin for closure of patent ductus arteriosus. Eur J Pediatr 2005; 164:135-40.
10. Mosca F, Bray M, Lattanzio M, Fumagalli M, Tosetto C. Comparative evaluation of the effects of indomethacin and ibuprofen on cerebral perfusion and oxygenation in preterm infants with patent ductus arteriosus. J Pediatr 1997;131: 549-54.

11. Patel J, Roberts I, Azzopardi D, Hamilton P, Edwards AD. Randomized double-blind controlled trial comparing the effects of ibuprofen with indomethacin on cerebral hemodynamics in preterm infants with patent ductus arteriosus. Pediatr Res 2000;47:36-42.

12. Pezzati M, Vangi V, Biagiotti R, Bertini G, Cianciulli D, Rubaltelli FF. Effects of indomethacin and ibuprofen on mesenteric and renal blood flow in preterm infants with patent ductus arteriosus. J Pediatr 1999;135:733-8.

13. Chotigeat U, Jirapapa K, Layangkool T. A comparison of oral ibuprofen and intravenous indomethacin for closure of patent ductus arteriosus in preterm infants. J Med Assoc Thai 2003;86 (suppl 3):S563-9.

14. Supapannachart S, Limrungsikul A, Khowsathit P. Oral ibuprofen and indomethacin for treatment of patent ductus arteriosus in premature infants: a randomized trial at Ramathibodi Hospital. J Med Assoc Thai 2002;85(suppl 4):S1252-8.

15. Fanos V, Benini D, Verlato G, Errico G, Cuzzolin L. Efficacy and renal tolerability of ibuprofen vs. indomethacin in preterm infants with patent ductus arteriosus. Fundam Clin Pharmacol 2005;19:187-93.

16. Heyman E, Morag I, Batash D, Keidar R, B aram S, Berkovitch M. Closure of patent ductus arteriosus with oral ibuprofen suspension in premature newborns: a pilot study. Pediatrics 2003;112:e354-8.

17. Pourarian S, Pishva N, Madani A, Rastegari M. Comparison of oral ibuprofen and indomethacin on closure of patent ductus arteriosus in preterm infants. East Mediterr Health J 2008;14:360-5.

18. Fakhraee SH, Badiee Z, Mojtahedzadeh S, Kazemian M, Kelishad R. Comparison of oral ibuprofen and indomethacin therapy for patent ductus arteriosus in preterm infants. Chin J Contemp Pediatr 2007;9:399403.

19. Hammerman C, Shchors I, Jacobson S, Schimmel MS, Bromiker R, Kaplan M, Nir A. Ibuprofen versus continuous indomethacin in premature neonates with patent ductus arteriosus: is the difference in the mode of administration? Pediatr Res 2008; 64:291-7.

20. Cherif A, Khrouf N, Jabnoun S, Mokrani C, Amara M B, Guellouze N, dkk. Randomized pilot study comparing oral ibuprofen with intravenous ibuprofen in very low birth weight infants with patent ductus arteriosus.

Sari Pediatri, Vol. 11, No. 6, April 2010 
Henry Gunawan dkk: Terapi farmakologis duktus arteriosus paten pada bayi prematur: indometasin atau ibuprofen?

Pediatrics 2008;122: e1256-61.

21. Sekar KC, Corff KE. Treatment of patent ductus arteriosus: indomethacin or ibuprofen? J Perinatol 2008; 28:S60-2.

22. Raju NV, Bharadwaj RA, Thomas R, Konduri GG. Ibuprofen use to reduce the incidence and severity of bronchopulmonary dysplasia: a pilot study. J Perinatol 2000;20:13-6.

23. Sharma PK, Garg SK, Narang A. Pharmacokinetics of oral ibuprofen in premature infants. J Clin Pharmacol
2003;43(9):968-73.

24. Cooper-Peel C, Brodersen R, Robertson A. Does ibuprofen affect bilirubin-albumin binding in the newborn infant serum? Pharmacol Toxicol 1996; 79: 297-9.

25. Ahlfors CE. Effect of ibuprofen on bilirubin-albumin binding. J Pediatr 2004; 144:386-8.

26. Zecca E, Romagnoli C, De Carolis MP, Costa S, Marra $\mathrm{R}$, De Luca D. Does ibuprofen increase neonatal hyperbilirubinemia? Pediatrics 2009;124:480-4. 